\title{
IJEP 2015 Awards and recognition of contributions:
}

1. Best reviewer: Dr Shanmukhi Somayajula, 4 reviews completed before time

2. IJEP Star of 2015: Dr Sita Jaylakshmi for her role as Associate editor, reviewer and author

3. Most popular Article: Predictors of outcome of surgery in adults with mesial lesional temporal lobe epilepsy by Manas Panigrahi, Sudhindra Vooturi, Rammohan Vadapalli, Shanmukhi Somayajula, Sailaja Madigubba, Sita Jayalakshmi

4. Best article: Application of mobile phones in epilepsy care by Lakshmi Narasimhan Ranganathan, Somasundaram Aadhimoolam Chinnadurai, Balasubramanian Samivel, Bhanu Kesavamurthy, Man Mohan Mehndiratta 